\title{
Radical, Sceptical and Liberal Enlightenment
}

\author{
James Alexander \\ Assistant Professor, Faculty of Economics, Administrative, and Social Sciences, \\ Dept. of Political Science, Bilkent University, Ankara, Turkey \\ jalexand@bilkent.edu.tr
}

\begin{abstract}
We still ask the question 'What is Enlightenment?' Every generation seems to offer new and contradictory answers to the question. In the last thirty or so years, the most interesting characterisations of Enlightenment have been by historians. They have told us that there is one Enlightenment, that there are two Enlightenments, that there are many Enlightenments. This has thrown up a second question, 'How Many Enlightenments?' In the spirit of collaboration and criticism, I answer both questions by arguing in this article that there are in fact three Enlightenments: Radical, Sceptical and Liberal. These are abstracted from the rival theories of Enlightenment found in the writings of the historians Jonathan Israel, John Robertson and J.G.A. Pocock. Each form of Enlightenment is political; each involves an attitude to history; each takes a view of religion. They are arranged in a sequence of increasing sensitivity to history, as it is this which makes it possible to relate them to each other and indeed propose a composite definition of Enlightenment. The argument should be of interest to anyone concerned with 'the Enlightenment' as a historical phenomenon or with 'Enlightenment' as a philosophical abstraction.
\end{abstract}

\section{Keywords}

Radical Enlightenment - Sceptical Enlightenment - Liberal Enlightenment - Jonathan Israel - John Robertson - J.G.A. Pocock

Let me begin with a general claim. There are three ways one can write the history of ideas. One can impose one's own idea on ideas found in past, in 
order to coerce them into a unitary history. One can abstract one particular idea from the past, in order to distinguish it in one's history from the plurality found elsewhere in the past. Or one can attempt to indicate what ideas meant to those who held them, in order to let one's history remain as plural as the past it is supposed to represent. ${ }^{1}$ These different ways of writing history have a remarkable influence on the shape of our ideas. They may be considered constitutive of them. They certainly condition them. As I shall argue, this is especially the case with 'heavily reified' ideas such as that of Enlightenment. ${ }^{2}$

The Enlightenment is something we suppose to have happened in the past. But it is also something which may be abstracted from the past so it is something happening in the present. This is why I say that the idea of Enlightenment is 'heavily reified': it was a thing of major concern; it is a thing of major concern. For us the Enlightenment is both a historical particular and a philosophical concept. And, as such, whatever the historians tell us about what it was is of decisive importance in shaping our sense of what it is.

We have been trying to define or characterise the Enlightenment for a long time. Kant said that his contemporaries lived in 'an age of enlightenment' but 'not yet an enlightened age.' ${ }^{3}$ It was available for some, not all. But by the end of nineteenth century, in the English language at least, 'the Enlightenment', with a definite article, and often capitalized, was spoken of as if it were an era in history as well as a phenomenon in philosophy. Thus was Kant's judgment overturned: the eighteenth century had been both 'an age of Enlightenment' and 'an enlightened age'. By the twentieth century Enlightenment was seen not only as the name of a conscious project carried out against the forces of reaction but also the name of the age in which this project was begun. As such it has been studied for a century, pro but sometimes contra, in great works by Ernst Cassirer, Theodor Adorno and Max Horkheimer, Alfred Cobban and Peter Gay, and more recently by

1 An instance of the first is Maurice Cowling, Religion and Public Doctrine in Modern England 3 vols. (Cambridge University Press, 1980-2001), instances of the second are Quentin Skinner, Liberty Before Liberalism (Cambridge University Press, 1997) and Richard Tuck, The Sleeping Sovereign: The Invention of Modern Democracy (Cambridge University Press, 2015), and an instance of the third is Michael Sonenscher, Before the Deluge: Public Debt, Inequality and the Intellectual Origins of the French Revolution (Princeton University Press, 2009). It should become obvious that the writings of Israel, Robertson and Pocock are meant to fit into these categories.

2 I owe the phrase 'heavily reified' to J.C.D. Clark. See note 27 below.

3 Immanuel Kant, 'An Answer to the Question "What is Enlightenment"?' (1784), in Political Writings ed. Hans Reiss (Cambridge University Press, 1991), pp. 54-6o, at p. $5^{8}$. 
Roy Porter, James Schmidt, Ian Hunter, Anthony Pagden, Dan Edelstein and many others. In the last thirty or so years the scholars have come to disagree about how many Enlightenments we should study. Of the three historians I want to consider here, J.G.A. Pocock has suggested that the Enlightenment is no singular phenomenon, and suggested that we should not speak of 'the Enlightenment' but of 'Enlightenments' in the plural; Jonathan Israel has argued that there are two Enlightenments; and John Robertson has maintained that there is only one Enlightenment.

How many Enlightenments are there? I shall argue here that we should not speak of one Enlightenment, two Enlightenments, or many Enlightenments. Instead we should speak of three Enlightenments. In this article, these three Enlightenments are abstracted from the works of three historians. This is in order to indicate that the argument I shall present is no mere speculation but based on authoritative historical understandings. But these historical works are far more digressive and detailed than I want to be here. So my purpose is not merely to offer a review of these historical works, but to indicate how historical ideas can be abstracted from them to be arranged into something like a system. This, I suggest, should enable us to make some progress in the analysis of Enlightenment.

To anticipate, the three types of Enlightenment shall be distinguished in terms of how they are successively more subtle about history:

1. Radical Enlightenment is the Enlightenment in which reason interrupts history, shattering all the older beliefs of tradition, authority and religion, ending the entire old world, now called dismissively the ancien régime, and inaugurating a new world built on rational ideals. This Enlightenment is revolutionary.

2. Sceptical Enlightenment is the Enlightenment in which reason is sought as a thread running through history, perhaps not evident at first glance, but susceptible to rational enquiry, so that the philosopher sees that the world is not what one thought: that the laws of history include those of unintended consequences, so that no matter what humans believed, there was rationality in history, sometimes hidden: here reason does not interrupt history but interrogates it, searches for the patterns and laws behind it. This Enlightenment is still progressive but not revolutionary, because it is tenderer to ordinary human beliefs, thinking that though they are unreasonable they may have reason in them.

3. Liberal Enlightenment is the Enlightenment in which no reason is postulated except the reasons of the reasoners, and where there is a further tenderness to ordinary human beliefs. This Enlightenment involves the 
view that we should respect the reasons that humans had in the past. Here, beliefs are what they mean to the believer: so history involves our understanding these beliefs in a historical sequence, seeing them as justified in their time and of major historical significance. In this context, Enlightenment requires us to adjust the formal status of these beliefs without changing their content, so that beliefs are believed within the frame of a civil order which is not itself dependent on those beliefs. Enlightenment here recognises that beliefs are not to be abandoned, or explained away, but retained with the provision that they are no longer meant to be the basis of the civil order or of civility.

I call the first form of Enlightenment 'Radical Enlightenment' because Israel has done so. I call the second 'Sceptical Enlightenment' (rather than following Israel in calling it 'Moderate Enlightenment') because it is qualitatively different from Radical Enlightenment, not merely derivative of it, and in such a way that it has a specifically sceptical content. It is sceptical not in any radically philosophical sense, but sceptical about the other forms of Enlightenment: sceptical about imposing abstract ideals on history and sceptical about taking the beliefs of believers at face value. And I call the third 'Liberal Enlightenment' because it neither imposes reason on history nor discovers reason behind history but has an open attitude to history and takes reason to be whatever anyone has supposed it to be and therefore, uniquely, justified no matter what that belief is.

The writings of the three historians I have mentioned diverge in many essentials. But the relative clarity of their conceptions of Enlightenment enables us to see how the literature could be considered a body of work that is more collaborative than perhaps anyone yet realizes. Robertson has reflected on the views of Israel ${ }^{4}$ and Pocock; ${ }^{5}$ Israel has reflected on those of Pocock 6 and Robertson; ${ }^{7}$ and Pocock has reflected on those of Robertson, ${ }^{8}$ though, as far as I know, not those of Israel: ${ }^{9}$ but only in advocacy of their own rather different

4 John Robertson, The Case for Enlightenment: Scotland and Naples 1680-1760 (Cambridge University Press, 2005), pp. 6-9.

5 Ibid., pp. 3-4.

6 Jonathan Israel, 'J.G.A. Pocock and the "Language of Enlightenment" in his Barbarism and Religion', Journal of the History of Ideas 77 (2016), pp. 107-27.

7 Jonathan Israel, Democratic Enlightenment: Philosophy, Revolution and Human Rights, 17501790 (Oxford University Press, 2011), pp. 5-6.

8 J.G.A. Pocock, 'Historiography and Enlightenment: A View of Their History', Modern Intellectual History 5 (2008), pp. 83-96.

9 Except indirectly in J.G.A. Pocock, 'Response and Commentary', Journal of the History of Ideas 77 (2016), pp. 157-171. 
ideas. Israel, though distinguishing two Enlightenments, clearly thinks that only one of them is Enlightenment proper. Robertson prefers the second of Israel's ideas, though he characterizes it differently and far more positively. Pocock has discerned yet another form of Enlightenment. Their views, at one level, are scholarly, subtle and complicated - based between them on at least a century of research - and as history can only adequately be assessed by other historians. Yet I think that it is possible to discern three ideal types of Enlightenment here, quite apart from the question of which of them, if any, we prefer. It is the purpose of this article to compare and contrast these three types of Enlightenment in order to indicate how even contradictory historical understandings of the Enlightenment can be brought together at a higher or more abstract argumentative level in order to say something about the nature of Enlightenment in general.

Jonathan Israel, the Andrew W. Mellon Professor in the School of Historical Studies at the Institute for Advanced Study, Princeton University, has published five great volumes on the origins, development and fate of enlightened ideas, running from the time of Spinoza to the American and French Revolutions and onwards, ${ }^{10}$ along with a summary of the entire argument in a short book entitled Revolution of the Mind.11

There are four things to be noted at the outset. Firstly, Israel flatly dismisses the view that there are many Enlightenments. "This seems to me far too vague and diffuse to be useful.'12 Secondly, he has a favoured point of focus. Like Pocock, who, as we shall see, reads the Enlightenment backwards and sideways from Gibbon, and, unlike Robertson, who reads the Enlightenment forwards from Bayle, Israel reads the Enlightenment forwards from Spinoza.

10 Jonathan Israel, Radical Enlightenment: Philosophy and the Making of Modernity, 16501750 (Oxford University Press, 2001), Enlightenment Contested: Philosophy, Modernity and the Emancipation of Man, 1670-1752 (Oxford University Press, 2006), Democratic Enlightenment: Philosophy, Revolution and Human Rights, 1750-1790 (Oxford University Press, 2011), Revolutionary Ideas: An Intellectual History of the French Revolution from the Rights of Man to Robespierre (Princeton University Press, 2014), The Expanding Blaze: How the American Revolution Ignited the World, 1775-1848 (Princeton University Press, 2017). Since the time of writing, a sixth has appeared.

11 Jonathan Israel, A Revolution of the Mind: Radical Enlightenment and the Origins of Modern Democracy (Princeton University Press, 2009).

12 Israel, Democratic Enlightenment, p. 6. 
But, thirdly, unlike them, he coerces a vast amount of material into his history of the Enlightenment. Fourthly, this is because of the original nature of his approach to the Enlightenment. For Israel, it is a two-in-one. He defines Enlightenment as a 'partly unitary phenomenon', which was 'everywhere, consciously committed to the notion of bettering humanity in this world through a fundamental, revolutionary transformation discarding the ideas, habits and traditions of the past either wholly or partially, this last point being bitterly contested among enlighteners.'13

It is only 'with its two main contending streams - Moderate and Radical [that] the Enlightenment can be understood as a single narrative.'14

There were and could be only two Enlightenments - Moderate (twosubstance) Enlightenment, on the one hand, postulating a balance between reason and tradition and broadly supporting the status quo, and, on the other, Radical (one-substance) Enlightenment conflating body and mind into one, reducing God and nature to the same thing, excluding all miracles and spirits separate from bodies, and invoking reason as the sole guide in human life, jettisoning tradition. ${ }^{15}$

This is a marvellously elegant reduction of the entire Enlightenment into one system: 'These two fundamentally different conceptions of progress - the radical democratic or alternatively Christian-Unitarian, on the one hand, and the 'moderate' and positively providential (Deist or religious), championing the monarchical-aristocratic order of society, on the other - were diametrically opposed to each other in their social and political consequences. They were also from the outset philosophically and theologically incompatible. ${ }^{16}$ And again: 'Between these two opposed conceptions obviously no compromise or half-way position was ever possible.'17

This twisting of two incommensurable lines together enables him to locate a great number of figures in his history. To take just the figures mentioned in The Revolution of the Mind, the moderates include Locke, Voltaire, Kames, Montesquieu, Reid, Hume, d'Alembert, Robertson, Smith, Ferguson, Kant, Turgot, Burke, Jacobi, Jones, Thelwall and Malthus, while the radicals include Spinoza ('the first major philosopher in the history of philosophy to proclaim

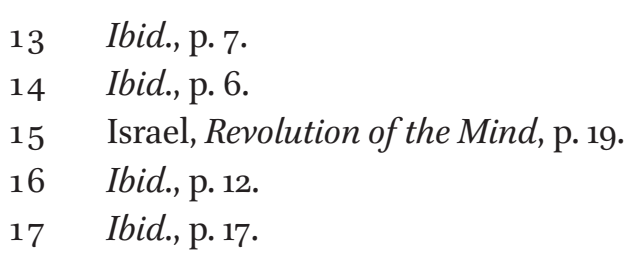


democracy the best form of government'), ${ }^{18}$ Bayle, Mably, Diderot, Raynal, Helvetius, d'Holbach, Boulanger, Price, Lessing, Macaulay, Priestley, Jebb, Paine, Struensee, Condorcet, Herder, Rush, Weishaupt, Barlow, Paulus, Forster, Cloots, Godwin, Frend, Wollstonecraft, Mirabeau, Sieyes, Brissot, Volney, Marechal and Cabanis.

The relation between Radical and Moderate Enlightenment is an ambiguous one. There is warrant in the way Israel describes them for seeing them as equal and opposite doctrines, both grounded in their own distinctive metaphysics. But there is also warrant for seeing them as distinguished so that one is superior to the other. There should be no doubt that Israel considers 'Radical Enlightenment' to be true enlightenment and 'Moderate Enlightenment' to be derivative of it. Perhaps he wants the two ideas of Enlightenment to be seen in both ways at the same time, metaphysically as if they are both completely justified in their own terms, but politically as if only one is justified - justified by its thorough commitment to revolution, while the other one collapses into compromise with the enemies of revolution.

The metaphysics which Israel depends on is very idiosyncratic and rather arcane, and even rather historically questionable, since it depends on the differences between Descartes' and Spinoza's philosophies: differences that often seem to have no place in the simpler and more political arguments of a century later. Be that as it may, the key distinction is between what he calls a one-substance and two-substance metaphysics. Descartes, Spinoza and Leibniz all agreed that a substance is something that 'is causally self-sufficient and indestructible. ${ }^{19}$ According to Israel, it is one-substance, that is, monistic philosophy that justifies the use of reason in the world. ${ }^{20}$ When admitting that there are some other candidates for being the originators of Radical Enlightenment, he writes: 'Spinoza ... with his one-substance doctrine - that body and soul, matter and mind are not distinct substances but rather one single substance viewed under different aspects - extends this 'revolutionary' tendency appreciably further, metaphysically, politics, and as regards man's highest good than do Descartes, Hobbes or Bayle.21 And again: 'The acceptance of a one-substance metaphysics ruling out all teleology, divine providence, miracles and revelation, along with spirits separate from bodies, and immortality of the soul, and denying that moral values are divinely delivered ... always went together with the idea that this man-made morality should

\footnotetext{
$18 \quad$ Ibid., p. 94.

19 Israel, Democratic Enlightenment, p. 231 n. 4.

20 Israel, Revolution of the Mind, p. 20.

21 Ibid., p. 2.
} 
provide the basis for legal and political legitimacy - and hence that equality is the first principle of a truly legitimate politics. ${ }^{22}$

If one-substance philosophy justifies the view that reason is ubiquitous and that everyone is entitled to be enlightened and emancipated, then twosubstance philosophy takes us in a very different direction. Two-substance, or dualistic, philosophy not only distinguishes body and soul but also, by analogy, distinguishes the activities of humans in the world from external principles that control them. This is the sense in which there is a qualitative difference between Radical and Moderate Enlightenment. We are told to notice the 'fundamental and irresolvable duality between the created and providential and non-created and non-providential schemes of reality.' ${ }^{23}$ The point for Israel is that the former is obliged to take a certain amount of what happens in the world on trust. Fate is not entirely, if at all, in our hands because there something else guiding us through history. Israel finds fault in any sort of providential doctrine, whether religious or secular, which has led exponents of Moderate Enlightenment into a partial abandonment of reason, since it makes them willing to find a compromise between reason and tradition.

By postulating divine planning and 'the finger of God' as the force behind both progress and the existing order, Ferguson, Kames and Adam Smith, along with Voltaire and Turgot, effectively resigned all prospect of viewing the existing order of institutions and social relations as basically defective ... The great limitation of the Moderate Enlightenment was that it was not open to its theorists to repudiate the existing hierarchical structure of society, or portray society as it had evolved as inherently defective, oppressed and systematically unjust, and hence wrongly organized for the purpose of advancing human happiness. ${ }^{24}$

This should be clear. Considered metaphysically, Radical and Moderate Enlightenment are distinct, each justified in its own terms, but considered politically, the first is clearly only a compromised and possibly even corrupted version of the other.

It is at the political end of the distinction where it seems as if the difference between Radical and Moderate Enlightenment is perhaps a quantitative one.

\footnotetext{
22 Israel, Democratic Enlightenment, p. 11.

23 Ibid., p. 19.

24 Israel, Revolution of the Mind, p. 14.
} 
For a two-substance philosophy also more prosaically distinguishes those who deserve to be enlightened from those who deserve to remain unenlightened, dividing all of humanity into two classes. While Radical Enlightenment is for all, Moderate Enlightenment is only for some. Israel quotes Voltaire saying that some nine-tenths of humanity 'do not deserve to be enlightened (les autres ne néritent pas que l'on les éclaire).' ${ }^{25}$ Voltaire and many others like Hume and Burke are condemned for being enlightened and yet trading with some or all of the supposed enmities of Enlightenment, that is, those old unenlightened matters of authority, tradition and religion. When seen this way, it may be that the Moderate Enlightenment is simply a theoretical enthusiasm for Enlightenment in the abstract accompanied by a practical sense that nothing abstract could ever be imposed on the world. So it is not really something metaphysically distinct from Radical Enlightenment but simply a corruption of it, a compromise between Radical Enlightenment and the unenlightened world.

No one has ever failed to notice that Israel's major purpose in his many books is to suggest that only Radical Enlightenment is Enlightenment properly conceived. Let us consider his definition of Radical Enlightenment:

Radical Enlightenment is a set of basic principles that can be summed up concisely as: democracy, racial and sexual equality; individual liberty of lifestyle; full freedom of thought, expression and the press; eradication of religious authority from the legislative process and education; and full separation of church and state. It sees the purpose of the state as being the wholly secular one of promoting the worldly interests of the majority and preventing vested minority interests from capturing control of the legislative process. Its chief maxim is that all have the same basic needs, rights, and status ... and that consequently all ought to be treated alike, on the basis of equity. ${ }^{26}$

Note the tense. This form of Enlightenment is obviously something which is still with us. And yet, as Israel describes it, it was something unleashed on the world in the late eighteenth century. Radical Enlightenment is fundamentally harnessed to revolution, not only to the French Revolution

\footnotetext{
25 Ibid., p. 6.

26 Ibid., pp. vii-viii.
} 
but to the 'heavily reified' idea of revolution which is the universalisation of the French Revolution. ${ }^{27}$ This is why Israel has as little patience with Robertson's Enlightenment as he has with Pocock's plural Enlightenments. Against Robertson, Israel insists that Enlightenment must issue in revolution. Robertson 'fails to capture the general consensus that what was needed and happening (or about to happen) was a giant leap forward, a vast revolutionary change. ${ }^{28}$ And again: 'Enlightenment is ... best characterized as the quest for human amelioration run between 168 o and 1800 , driven principally by 'philosophy' ... leading to revolutions in ideas and attitudes first, and actual practical revolutions second. ${ }^{29}$ This is why Israel thinks that Moderate Enlightenment may not qualify as Enlightenment at all. 'The social and political doctrines of Hume, Ferguson, Smith, Turgot and Voltaire', he writes, 'were simply inadequate and insufficient for tackling the major structural problems Europe faced at the time. ${ }^{30}$ Both Radical and Moderate Enlightenment sought human amelioration. But if Moderate Enlightenment sought 'compromise with the existing order' then it may be that, in the end, Israel does not consider it a form of Enlightenment at all. ${ }^{31}$ Especially if, as he puts it, 'all Enlightenment by definition is closely linked to revolution. ${ }^{32}$

There is much to admire Israel's sketch of Radical Enlightenment. No matter how flawed Israel's writings may be in explaining historical particulars, they enable us to distinguish an original, simple form of Enlightenment from any another form. Whether Israel can be considered a theorist of two types of Enlightenment, however, is doubtful, because he is committed to the priority and superiority of one over the other. And, unlike Robertson, he has done little to indicate the positive vision of what he calls Moderate Enlightenment and what I call Sceptical Enlightenment.

\section{$3 \quad$ Sceptical Enlightenment}

John Robertson, Emeritus Professor of the History of Political Thought at the University of Cambridge, has written The Case for Enlightenment: Scotland

27 See J.C.D. Clark, Thomas Paine: Britain, America and France in the Age of Enlightenment and Revolution (Oxford: Clarendon Press, 2018), p. 102.

28 Israel, Democratic Enlightenment, p. 5 .

29 Ibid., p. 7.

$30 \quad$ Israel, Revolution of the Mind, p. 121.

31 Israel, Democratic Enlightenment, p. 11.

32 Ibid., p. 7 . 
and Naples 1680-1760 (2005) and The Enlightenment: A Very Short Introduction (2015), as well as several papers on the subject of Enlightenment.

In The Case for Enlightenment Robertson is dismissive of the idea that there are many Enlightenments, offering a very reasonable objection to it: 'The unrestricted definition of Enlightenment, or its alternative, the admission that there were multiple Enlightenments, has rendered the subject so blurred and indeterminate that it is impossible to make any assessment of its historical significance. ${ }^{33}$ His book is therefore, as against Pocock, a study of 'Enlightenment in the singular, with or without the definite article. ${ }^{34}$ In this, Robertson aligns himself with Israel.

But Robertson also argues with Israel. Historically, Robertson is critical of Israel's view that Enlightenment had its origins in the radical assault on the Christian religion of between $168 \mathrm{o}$ and 1740 .

'The Enlightenment' as it is understood in this book remains the movement which began in the 1740 s and ended in the 1790 os.... By no means do I accept Israel's view that 'the real business was over' by the 1740s. What was over by then, in all but a few privileged enclaves, was the radical assault on the foundations of the Christian religion; it was over because the authorities, Protestant as well as Catholic, had effectively suppressed it, or at least curtailed its expression. Instead, what characterized the Enlightenment from the 1740s onwards was a new focus on betterment in this world, without regard for the existence or non-existence of the next. For such betterment to be achieved, it was indeed important that those who claimed to exercise authority in this world on the basis of their knowledge of the next should be removed to the sidelines. But intellectual effort was now concentrated on understanding the means of progress in human society, not on demolishing belief in a divine counterpart. ${ }^{35}$

In other words, Robertson is offering a singular Enlightenment very different to Israel's 'Radical Enlightenment'. What Robertson does not say is that his own Enlightenment is a version of what Israel has called 'Moderate Enlightenment': except it is a positive version of it, not a negative one. What we should notice is that it certainly resembles Israel's Enlightenment in being primarily defined in terms of betterment.

\footnotetext{
33 Robertson, The Case For Enlightenment, p. 43.

34 Ibid., p. 45 .

35 Ibid., p. 8.
} 
Robertson denies that Enlightenment was an ideal type: 'The Enlightenment for which I have made a case here is one whose significance it is possible to assess as a historical phenomenon rather than as an arbitrary philosophical construct. ${ }^{36}$ Nonetheless his definition of Enlightenment does make it sound like an arbitrary philosophical construct. He defines Enlightenment as:

The commitment to understanding, and hence to advancing, the causes and conditions of human betterment in this world. ${ }^{37}$

It is further specified as having three elements: first, 'the deliberate attempt to join mental and moral philosophy in a single science'; second, the attempt to enquire into 'the conditions specifically of material betterment, the subject matter of political economy'; and third, the attempt 'to investigate the structure and manner of societies at the various stages of their development.' ${ }^{38}$ Robertson's historical account begins with the view that Pierre Bayle had expressed in Pensées Diverses in 1683: where 'he had defended the possibility of a society of atheists, living in a tolerable state of sociability out of no more than self-interest, with no reference whatever to the life to come. ${ }^{39}$ Robertson shows how this thought was taken up first in Naples and then in Scotland, where (in Pocock's useful summary of Robertson's argument) 'it was answered first by a moral philosophy that made humans capable of society without needing recourse to God, and then by a political economy that elaborated their capacities in the settings of history and commerce. ${ }^{40}$ Enlightenment originated in atheism - or at least the possibility of a society of atheists. The book traces the emergence of doctrines of 'sociability' out of doctrinal 'atheism' by looking at Bayle, rather than Spinoza, and examining the tradition of 'the encounter between the Augustinian rigorism of Pascal and Port Royal and the revived, supposedly Christianized Epicureanism championed by Gassendi and his followers.' ${ }^{41}$ In detail this means Pietro Giannone and Giambattista Vico who were followed by Antonio Genovesi, Ferdinando Galiani, Guiseppi Maria Galanti, Gaetano Filangeri and Francesco Mario Pagano in Naples, and followed by Francis Hutcheson, Lord Kames, Adam Ferguson, William Robertson, Thomas Reid, John Millar, David Hume and Adam Smith in Scotland, with an

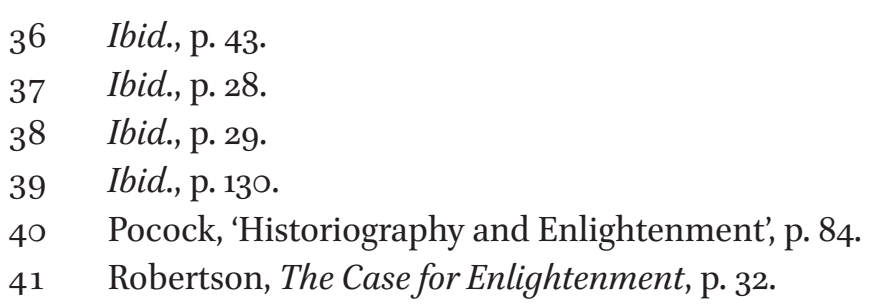


emphasis on, as he puts it in his chapter titles, 'Vico, after Bayle' and on 'Hume, after Bayle and Mandeville., 42

It may be to narrow down Robertson's analysis too far to emphasize Mandeville, but it seems to me that it is Mandeville's argument, and the answers to it, that are most characteristic of this second type of Enlightenment. This argument, as far as I can see, is ignored by Israel. ${ }^{43}$ Though it is well known to certain historians of eighteenth century thought, ${ }^{44}$ it is not well known enough by other historians of political thought or by non-historians. The argument has perhaps two steps: one is the original Epicurean, Baylean or Mandevillean postulate and second step is what one does to complicate and to some extent answer the original postulate. The original postulate is a narrowed view of human motivation. In Robertson's words: 'With Bayle, both [Vico and Mandeville] accepted that man is driven by his passions. In consequence, both presupposed that man is not naturally sociable, and set out to explain how he becomes sociable over time, by learning that his selfish passions are most fully satisfied in society ... 45 The argument of Mandeville in The Fable of the Bees (1714) was bleak and amusing but also consoling. He assumed that man is only motivated by his own passions, and that everything in society is the result of the agglomeration of selfish activities - hence the slogan 'private vices, public benefits'. This was a paradox: in Mandeville's words, 'that man is so unaccountable a creature as to act most commonly against his principle.46 Mandeville thus complacently suggested that one step was sufficient to generate good order. The second step, taken in one direction by Vico, and in another by Hume and Smith, also Rousseau, was to add a further argument.

Vico, according to Robertson, refuted Bayle in his first New Science of 1725 by claiming that all societies originate with a religion (a claim he based on the fact that all humans he had studied had a sense of providence and made

42 Ibid., pp. 44-45.

43 Israel discusses Mandeville briefly in Radical Enlightenment, pp. 623-6. Hume is discussed at some length in Democratic Enlightenment, pp. 209-32 and Smith on pp. 233-48. There is reference to the invisible hand - "The "revolution" that counted [for Hume and Smith] lay in the past and was devised not by humans but by an "invisible hand"' (p. 236) - but no reference to the principle of unintended consequences.

44 See, for instance, Istvan Hont and Michael Ignatieff eds. Wealth and Virtue: The Shaping of Political Economy in the Scottish Enlightenment (Cambridge University Press, 1983), Knud Haakonssen, Natural Law and Moral Philosophy: From Grotius to the Scottish Enlightenment (Cambridge University Press, 1996), Donald Winch, Riches and Poverty: An Intellectual History of Political Economy in Britain, 1750-1834 (Cambridge University Press, 1996).

45 Robertson, The Case for Enlightenment, p. 276.

46 Quoted in ibid, p. 268. 
provision for burials and marriage). He then argued that it is was no accident that Mandeville could get from 'private vices' to 'public benefits', no mere paradox. On the contrary, according to Axiom VII of the third New Science of 1744, the fact that it was out of ferocity, avarice and ambition that civil order emerges 'proves that there is divine providence and that it is divine legislative mind, which out of the passions of men, all devoted to their private utility, for the sake of which they would live as wild beasts in a state of solitude, has made civil institutions by which they may live in human society. ${ }^{47}$ Hume, Rousseau and Smith, according to Robertson, all argued in a different way, but each offered an argument that was, in effect, a second step designed to indicate exactly how Mandeville's conclusion, while correct, was not a paradox but was true because of some additional factor. As in Vico, the cause was not simply vice or passion. Each of them agreed with the original assumption of Mandeville that man begins with passions. But each wanted a subtler story about human history, and each suggested that there was an additional factor that emerged in human consciousness of self, that moderated the passions and made sociability a positive achievement. For Hume, it was our artificial, not natural, sense of justice, that emerges out of encountering the inconveniences that result from acting on our passions. ${ }^{48}$ For Rousseau, it was our capacity for voluntary moral choice. ${ }^{49}$ For Smith, it was the existence of an 'impartial spectator' by which we judge our own actions..$^{50}$

Robertson traces the rise of moral theory, civil history and political economy in Scotland and Naples, but his Enlightenment is about the fact that a priori reasoning was out of place. 'Like Mandeville, Hume believed that we must reason a posteriori concerning human behaviour. ${ }^{51}$ For Robertson, Enlightenment was such reason, as applied to the passions, beginning with the observation that man is passionate, and then applied to the question of how sociability could emerge if originally man was only the subject of his passions. This Enlightenment, Robertson claims, began with a study of human nature, involved the making of moral philosophy into a single science and finally ended in an account of history that explained how humanity moved from a savage or barbarian state to civilisation. ${ }^{22}$ The idea of Enlightenment was that it is

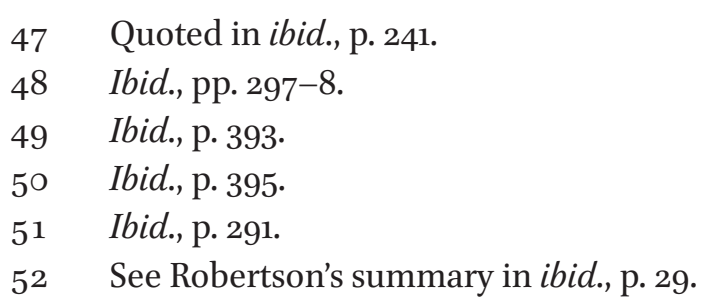


only by studying the continuities of this history that we can hope to better human society.

The difference between Radical Enlightenment and Sceptical Enlightenment is clearest when we consider what they make of revolution. I have already quoted Israel saying that Enlightenment requires 'fundamental, revolutionary transformation', and that 'all Enlightenment by definition is closely linked to revolution.'53 In his book Enlightenment: A Very Short Introduction, Robertson emphatically states the opposite view. Enlightenment, he says, had 'a novel approach to politics ... which was swept aside rather than fulfilled by the Revolution of $17899^{\prime} \cdot 4$ This novel approach was the idea that philosophers, as well as offering counsel to rulers in the old manner, should ensure that rulers should not dominate discourse in society, and should ensure this by directing public opinion. Hence, as far as Robertson was concerned, 'the Revolution was the antithesis of the Enlightenment'. 'Where Enlightenment philosophers looked to an informed public opinion to exert an indirect, restraining influence on government, the revolutionaries were committed to the overthrow of the ancien régime by direct overthrow. 55

We could not have more diametrically opposed views than these. Let me state it clearly:

Either Enlightenment requires Revolution.

Or Enlightenment is antithetical to Revolution.

It is necessary to name these variants of Enlightenment so we can distinguish them at all times. Radical Enlightenment requires Revolution - a 'heavily reified' revolution - while Sceptical Enlightenment forbids it. This, if nothing else, would be enough to demonstrate that as a single entity, 'Enlightenment' is clearly contradictory. ${ }^{56}$

I shall say something more about the contrast between these two views later in this article. But, for the moment, it is not enough to make sense of Enlightenment in terms of such an antithesis or antinomy. For there is a third type of Enlightenment, which I call Liberal Enlightenment.

53 Israel, Democratic Enlightenment, p. 7 .

54 John Robertson, The Enlightenment: A Very Short Introduction (Oxford University Press, 2015), p. 13 .

55 Ibid., p. 116.

56 C.f. Roger Scruton: 'It would be absurd to suppose that the Enlightenment is one phenomenon.' From An Intelligent Person's Guide to Modern Culture (London: Duckworth, 1998), p. 21. 
J.G.A. Pocock, Harry C. Black Emeritus Professor of History at John Hopkins University, has written much about the subject of Enlightenment, not least in the six volumes of his great work Barbarism and Religion (1999-2015). Just as we may point to Israel having his obvious hero in Spinoza, and Robertson having his apparent hero in Bayle, along with Vico and Hume, so Pocock has in his later writings had Gibbon as his hero. Barbarism and Religion is a study of Gibbon's Decline and Fall of the Roman Empire. In the first volume, subtitled The Enlightenments of Edward Gibbon, he outlines his view that we should not speak of 'the' Enlightenment but speak of many Enlightenments. But I shall quote the summary of the position from an article entitled 'Historiography and Enlightenment':

'Enlightenment' is a word or signifier, and not a single or unifiable phenomenon which it consistently signifies. There is no single or unifiable phenomenon describable as the 'Enlightenment,' but it is the definite article rather than the noun which is to be avoided. In studying the intellectual history of the late seventeenth century and the eighteenth, we encounter a variety of statements made, and assumptions proposed, to which the term 'Enlightenment' may usefully be applied, but the meanings of the term shift as we apply it. ${ }^{57}$

Pocock refers to Robertson's 'admirably challenging' Case for the Enlightenment, and in his own article wants to show how, at the very least, it is possible to sketch an Enlightenment that is not Robertson's. He admits that Robertson's history which runs from Bayle to Vico in one direction and Hume in another merges with the 'dominant paradigm' by which the Enlightenment is seen as a "non-theocentric "philosophy" of civil society, with political economy and a history of society and l'esprit humain among its outgrowths'.58 Against this, Pocock does not so much argue as simply point to another possible instance of something that it is useful to call Enlightenment. This, emphatically, cannot begin with a society of atheists because it deals not with 'the origin of civil society but its relation to a different society, namely the Church. ${ }^{59}$

57 J.G.A. Pocock, 'Historiography and Enlightenment', p. 83. For the full citation see note 8 above. This paper is in effect a summary of the position defended at more length in Barbarism and Religion Volume v: Religion: The First Triumph (Cambridge University Press, 2010).

$58 \quad$ Ibid., p. 84 .

59 Ibid., p. 85 . 
The Enlightenment to which Pocock wants to draw our attention is distinctive in that it is neither revolutionary against religion (like Radical Enlightenment) nor sceptically subversive of it (like Sceptical Enlightenment) but allows religion to be retained. This is what makes this idea of Enlightenment distinctively Liberal - a word Pocock does not use in this context. Pocock refers to lesser known figures as typical of this Enlightenment: Jean Le Clerc, Isaac de Beausobre and Johann Jakob Brucker. These writers supposed that one could be committed to Christ crucified but committed to almost nothing else. This had consequences for theology, for history and for politics.

The consequence for theology was that almost every claim about Christ was a sceptical one - the opposite of a dogmatic one - because it could not be known. Pocock shows that Le Clerc in 1685 wrote to John Locke saying that he intended to apply the arguments of The Essay on Human Understanding to ancient literature, which included patristic literature. Pocock explains that the first Christians had had an experience they could not put into words, but had to say something about. 'Their position was the reverse of Wittgenstein's: whereof they could not speak, thereof they could not remain silent. ${ }^{60}$ Le Clerc argued that though we believe in Christ crucified, we have no direct knowledge of it, and so have to rely on the written testimony of those who witnessed it, and therefore, by the time we come to consider it, we inevitably commit ourselves to the study of a succession of contested interpretations of the original event. Hence Jean Le Clerc took 'a long step towards replacing theology with the history of theology'. Later on, Brucker in Historia Critica Philosophiae (1742), without disputing the witness of the early Christians, argued against 'patristic and scholastic theology' in terms of the 'philosophical revolution wrought by Bacon, Grotius and Locke.61 This was enlightened, Pocock argues, because he was putting the Christian tradition to the question - even though he was not putting the Christian truth to the question.

The consequence for history was that one had to attend to the varieties of what it has been possible to think. This is something which Pocock obviously admires because it runs close to his own historical inclination to take historical figures on their own terms or, at least, in terms of reasonable historical 'contexts' - and thereby not ignore, reduce or subvert religion. Isaac de Beausobre in Histoire de Manichée et du Manichisme (1734-39) 'held that the entire history of heresy and orthodoxy could be explained in terms of ancient philosophy's inability to believe that God had created matter out of nothing, a belief that even Christians took some time to formulate, so that its history had to

\footnotetext{
6 o Ibid., p. 87 .
}

61 Ibid., p. 9 o. 
be written.62 I said in the introduction of this article that this third type of Enlightenment is the subtlest about history. This is because it did not ignore or dismiss history, or subvert or rationalize it, but attempted to see it sympathetically, as a set of struggles to say what had been experienced. Pocock shows the importance of this for historical writing by referring to Gibbon's Decline and Fall of the Roman Empire. Gibbon is an unusual figure not only because he was enlightened - Venturi once suggested he was the only Enlightenment figure to come from England ${ }^{63}$ - but also because, in the end, he seconded Burke's judgment of the French Revolution. Pocock has made much of the fact that Gibbon's ironic and corrosive attitude to early Christianity in the fifteenth and sixteenth chapters of the Decline and Fall, published in 1776 , was replaced by a far more respectful historical engagement with Christianity in the twenty-first and forty-seventh chapters published in 1781 and 1788: where he considered the arguments leading up to the Council of Nicaea and the Council of Chalcedon 'in considerable detail'. Pocock observes: 'He may - indeed he does - think the entire debate founded in a false philosophy of substances, essences and natures, but he knows this philosophy to have been deeply and authentically held by men of powerful intellect, and he recognizes that its history can only be written by taking it seriously. He avoids the Voltairean error of dismissing the histories one does not like ... ${ }^{64}$ In short, Gibbon knew that a philosophy in which he does not himself believe has been believed in by honourable men. It was, for Gibbon, and is, for Pocock, necessary for history to be capable of showing this. Even though "Western "history" has been related as, and through, the supersession of the sacred, it cannot be related without the constant presence of the sacred it claims to supersede. ${ }^{65}$

The consequence of this for politics was that any theological or even ecclesiastical claim was seen to be tentative, and therefore could not be decisive in laying down the foundations of civil order. Pocock is rather inexplicit about this in the paper 'Historiography and Enlightenment', where he only remarks that this sort of Enlightenment reduced Christ to discussion of him, and had the effect of 'lessen[ing] the authority which any church might claim as continuing [Christ's] mission, in competition with that of civil magistrates'. (He continues: 'and there are obvious affinities here with Bayle's suggestion that neither God

\footnotetext{
$62 \quad$ Ibid., p. 86.

63 Franco Venturi, Utopia and Reform in the Enlightenment (Cambridge: Cambridge University Press, 1971), p. 132

64 Pocock, 'Historiography and Enlightenment', p. 92.

65 Ibid., p. 96.
} 
nor a knowledge of God was necessary to the being of civil society'.) ${ }^{66}$ But in his other writings, Pocock has been explicit about it.

Pocock does not call what he is writing about a 'Liberal Enlightenment'. ${ }^{67}$ But it should be obvious that this Enlightenment is Liberal because it involves the establishment of an order in which rival religions can trade but where no one religion determines the ordering principles of that order. In the first volume of Barbarism and Religion he says that Enlightenment 'may be characterised in two ways':

first, as the emergence of a system of states, found in civil and commercial society and culture, which might enable Europe to escape from the wars of religion without falling under the hegemony of a single monarchy; second, as a series of programmes for reducing the power of either churches or congregations to disturb the peace of civil society by challenging its authority. 68

In the second volume he emphasises its intellectual side, saying it is a 'reduction of philosophy and theology from perception of reality to sociable discourse. 69 But in his most recent writings on the subject the political relevance of this Enlightenment is that it issues in 'the social control of religious debate. ${ }^{70}$ Or, in his pithiest formulation, it is 'the will to subject disputatious religion to the imperatives of civil society.' ${ }^{71}$

$66 \quad$ Ibid., p. 94.

67 In fact, it has been called 'clerical and conservative' not only by Pocock in, for instance, 'Clergy and Commerce: The Conservative Enlightenment in England', in R.J. Ajello et al eds., L'Età de Lumi (Naples, 1985), Vol. I, pp. 523-565, but also by B.W. Young, who has made much of Pocock's emphasis on the religious contribution to the Enlightenment. See B.W. Young, 'John Jortin, Ecclesiastical history, and the Christian Republic of Letters', The Historical Journal 55 (2012), pp. 961-981, at p. 961. But even he sees that if it was 'clerical and conservative' it was also 'lay and liberal' (ibid., p. 973). Unlike Pocock and Young, since I am not writing as an historian, I am less interested in who originated it than in what it is - hence my emphasis on 'liberal'.

68 J.G.A. Pocock, Barbarism and Religion, Volume I: The Enlightenments of Edward Gibbon, 1737-1764 (Cambridge University Press, 1999), p. 7.

69 J.G.A. Pocock, Barbarism and Religion, Volume II: Narratives of Civil Government (Cambridge University Press, 1999), p. 19.

70 J.G.A. Pocock, 'Afterword: The Machiavellian Moment: A Very Short Retrospect and Re-Introduction', History of European Ideas 43 (2017), pp. 215-221 at p. 218.

71 J.G.A. Pocock, 'Commerce, Credit and Sovereignty: The Nation-State as Historical Critique', in Markets, Morals, Politics: Jealousy of Trade and the History of Political Thought eds. Bela Kapossy, Isaac Nakhimovsky, Sophus Reinert, Richard Whatmore (Harvard University Press, 2018), pp. 265-284, at p. 269. 
Pocock considers this form of Enlightenment to be genuinely distinct from other Enlightenments, because whereas Israel's Enlightenment can only see the history of Christianity as an obstruction and Robertson's Enlightenment can only see the history of Christianity as something requiring rationalisation, Pocock's Enlightenment seeks to explain, as far as it is possible to explain, the history of Christianity as a cause of Enlightenment. Israel's and Robertson's Enlightenments cannot do this: they do not even attempt it because, for these Enlightenments, Christianity is something that can never be understood in its own terms.

It is important to distinguish the historical and political aspects of this type of Enlightenment. The historical aspect was discovered by figures like Le Clerc: it mattered to Gibbon, and it also matters to Pocock. It is the view that, historically considered, beliefs are what they mean to the believer: they are not to be eliminated or explained away in terms of something else. Pocock clearly, writing in his own capacity as a historian, thinks that this simply gives us better history than any history which involves the imposition of a Radical intellectual scheme or the extraction and elaboration of a Sceptical argument. The political aspect of this Enlightenment, though it can be distinguished from the historical aspect, is related to it: at least by analogy and even as a possible consequence. This is because treating beliefs as what they mean to a believer is an element of Liberalism, as we have come to know it by name since its clarification since the nineteenth century.

It should be obvious that the decisive difference between Sceptical and Liberal Enlightenment is in politics. Not only is Liberal Enlightenment not so much concerned with 'human betterment' as with what we might call 'better conditions for self-betterment', but, unlike Sceptical Enlightenment, it is revolutionary even if only in the minimal sense that it requires a political shift so that religion no longer supplies the actual basis for civil order - though it may supply the apparent or historic basis of that order.

It remains to clarify the relations between all three forms of Enlightenment.

I want to argue that, for the sake of clearer understanding, both historical and philosophical, we should see that the Enlightenment is neither a singularity a single phenomenon or a single event in history - nor an indefinite plurality. The historians have sketched three forms of Enlightenment. From these I am concerned to abstract three ideal types which will sum between them the meanings of the 'heavily reified' Enlightenment of the long eighteenth 
century. They also will enable us to attempt to capture the three major ways we have of making sense of Enlightenment now. By 'ideal types' I mean that they do not describe the enlightened positions of any particular author, and certainly not the positions of major or complicated authors - our Bayles, Montesquieus, Humes, Rousseaus, Kants - who of course are likely to straddle the types. On the contrary, I take these three types indicate three possible logics of enlightenment.

At the time of writing I consider these three forms of Enlightenment to be exhaustive of what Enlightenment is - at the level of abstraction at which I am dealing with them. The level of abstraction here is clearly not a historical level of abstraction, but a philosophical one: and yet I have used historical authorities in order to justify the presence of these three forms of Enlightenment. Nonetheless, I am seeking to achieve a recognition at a higher level of abstraction which is perhaps philosophical or somewhere between philosophy and history - hence my interest in this being read in The Journal of the Philosophy of History. Only a form of Enlightenment which can be abstracted in this way counts as what I am calling a logic of Enlightenment. As I say, at the moment, I do suppose that there are only three such logics. But demonstrating this is impossible until there is counter-argument, or another is found. For the moment, then, there is no fourth. It would perhaps need a historian to propose a fourth, and I have not seen anyone who has yet found one. Of course, after 1789, romanticism, reaction and a historical sense of loss accompanying progress, complicated Enlightened thought, but whether Marxism or something similar from the nineteenth century - which, anyhow, is getting rather late - could be the type of another mode of Enlightenment is as yet unclear to me.

So let me attempt to draw the threads together.

Enlightenment, in general, means 'awakening', 'illumination', 'clarification'. It is associated with a religious revelation such as those associated with the Buddha's four noble truths or the truth of Christ crucified and resurrected. In each case there is a moment before when one is unenlightened and a moment after when one is enlightened. However, in the distinctive and particular sense of Enlightenment we are concerned with here, we refer to something similar to a religious enlightenment but antithetical to it in certain respects. It is not religious, but secular. We sometimes call it 'the Enlightenment'. But the definite article 'the' is deceptive. The word 'the' does adequately point to the fact that we are talking about a distinctive and particular sense of Enlightenment but it also misleadingly suggests we are justified in talking about a singular Enlightenment. If we cannot agree about what this singular Enlightenment is - what its character is - then we seem to be condemned to fall back on the weak use of the term to refer to a particular historical era, by which 'the 
Enlightenment' would refer only to the long eighteenth century. The problem with this is that it would mean that everything which took place in that era was enlightened. So it seems to me that Enlightenment has to refer to something which happened, a particular something - even though we may disagree about the nature or character of this something. And as such it has to be characterised. It is to the credit of Israel, Robertson and Pocock that they have tried to characterise it. But what I want to claim is that 'the Enlightenment', though specific is not singular. It meaningfully refers to the forms of Enlightenment each of the three historians has singled out and which, here, I have brought together into triplicity.

In addition, though Enlightenment refers to something which happened, it also refers to something which may be happening and ought to happen now, depending on the attitude we take to it in the present. If 'the' Enlightenment was an historical experience, then Enlightenment, considered in the abstract, once it is shorn of its contingent historical determinants, is a present possibility.

So there are three forms taken by Enlightenment. And these are contradictory.

First, there is Radical Enlightenment, in which Enlightenment involves a radical break with the past: so that old ideas of Religion, Tradition and Authority shall be replaced by new ideas of Liberty, Equality and Fraternity: or, as I have put it elsewhere, 'sacrality, hierarchy and specificity' shall be replaced by 'secularity, equality and generality'72 It requires Revolution, the establishment of a new order, the replacement of an ancien régime by a novo ordo saeclorum.

Second, there is Sceptical Enlightenment, in which Enlightenment resists Revolution as absolute folly and instead urges that Reason be embodied not in the imposition of a priori ideals but in an a posteriori understanding of what has really taken place in history. This is not to force any improvement on the world, but to recognise the improvement that has come out of miscellaneous human activities, as unintended consequences of those activities, in such a way that they can retrospectively be seen as following certain patterns. Here, the major distinction is between those who are enlightened, and see the world for it is - a world in which the older ideas of religion, tradition and authority cannot be dispensed with no matter how implausible they are to the enlightened mind - and those who are not enlightened ('barbarians', 'enthusiasts', 'the superstitious'). Sceptical Enlightenment involves a 'double truth': one truth for the enlightened, and another for the worldly.

Third, there is Liberal Enlightenment, in which Enlightenment seeks neither to eliminate the older beliefs, nor subvert them while supporting them,

72 James Alexander, 'A Dialectical Definition of Conservatism', Philosophy 91 (2016), pp. 215232 , at p. 230 . 
but seeks to reframe them: by taking them out of the frames of their own making and placing them within a greater frame in which all can exist together. This frame will be secular rather than itself religious, but a frame in which there will be no further assaults on any belief.

What I am suggesting, then, is that Enlightenment is a dialectical phenomenon, that is to say, a contradictory triple-natured phenomenon, which was both revolutionary and not revolutionary, which cut history into two and left history as it was, which imposed enlightened ideas on order, which found enlightened phenomena beneath confusion and which established an enlightened framework on unenlightened human practices. It was all of these things: it is all of these things. There was no single Enlightenment, because there was at root an active contest in the response to the supposed decline of the older beliefs: a contest over how to think about history, politics and religion afresh in a situation where the one thing which was certain was that we were not going to take the old ideas for granted. Religion, tradition and authority would not be what they were before, for they would be eliminated, or understood in a way that was subversive of them, or framed in a radically novel setting. But no one could claim a monopoly over what should happen because there was no one thing which could happen. At every point there was a tension, a triangular tension, between the radically revolutionary approach, the sceptically subversive and supportive approach, and the liberally accommodating approach: and it is in the tension between these three that we can best locate the Enlightenment we have been concerned with in the last three centuries.

Each type of Enlightenment has its own distinctive paradox.

The paradox of Radical Enlightenment is that in opposing the 'superstition and enthusiasm' of the old unenlightened beliefs it can generate superstitions and enthusiasms of its own. Pocock quotes Gibbon's Memoirs, which were drafted after the beginning of the French Revolution: 'Nor could I approve', when in France, 'the intolerant zeal of the philosophers and Encyclopaedists, the friends of d'Olbach and Helvetius: they laughed at the scepticism of Hume, preached the tenets of Atheism with the bigotry of dogmatists, and damned all believers with ridicule and contempt. ${ }^{73}$ Pocock drily summarises the point: 'Reason, even the reason of Enlightenment, could beget its own form of enthusiasm. ${ }^{74}$ If Radical Enlightenment is as committed to its beliefs as the older order, then the status of its beliefs may seem to be no different from the beliefs it has destroyed. This is simple and obvious. The paradoxes of Sceptical and Liberal Enlightenment are rather more complicated.

73 Quoted in Pocock, Barbarism and Religion, Vol. I, p. 248.

74 Ibid., p. 71. 
The paradox of Sceptical Enlightenment becomes evident as soon as we consider Sceptical Enlightenment in relation to the Revolution which it does not want. Before the Revolution Sceptical Enlightenment is against creating a unified enlightened order: it asks those who are enlightened to see the world for what it is, and leaves the rest to live as before. After the Revolution it can no longer defend the double truth: one truth for the enlightened, and one truth for the enlightened. The Revolution has let the cat out of the bag. From now on there must only be one truth. So Sceptical Enlightenment must either seize one horn of what is now a dilemma and become what is now called 'conservative' (consider Gibbon and Burke and quite possibly Hume), or it must seize the other horn and actively and consciously attempt to realise on behalf of everyone the ideal which was formerly concealed from all but the enlightened and become 'progressive'. This is an explanation, if one were needed, about why the Scottish Enlightenment was destroyed - or divided - by the French Revolution. The tradition which came down from Hume and Smith could no longer be scientific or sceptical because it had been dragged into political debate and had to commit to one side or another. ${ }^{75}$ It has not been easy to be sceptical about politics since 1789 . Bentham and Paine between them made it more or less impossible.

The paradox of Liberal Enlightenment is that the enlightened frame will always remain in tension with the unenlightened beliefs existing within the frame. This is for the reason that believers will not always have good reason to support a liberalism which has the effect of relativising and depoliticising their beliefs - telling them that their beliefs are not absolutely true and telling them that their beliefs cannot be the basis of the entire order. Furthermore, unlike Radical and Sceptical Enlightenment, Liberal Enlightenment abjures any singular claim about the 'betterment' that is supposed to result from Enlightenment. If Radical Enlightenment is eager to bring theory in to change practice; and if Sceptical Enlightenment - as even Israel seems to admit - is a form of Enlightenment requiring change and certainly justifying betterment, then Liberal Enlightenment, with its concern to allow beliefs mean what they mean to be believer, has a laissez-faire attitude to ends. All it offers is an original condition: at most, it wants to establish the conditions for people or groups of different views to pursue their own betterment.

The simplest form of Enlightenment is without doubt Radical Enlightenment. It divides before from after by Revolution. It involves an absolute break with the past. It involves, as I have put it elsewhere, the establishment of the

75 This is detailed in Knud Haakonssen, Natural Law and Moral Philosophy, cited above, and John Burrow, Whigs and Liberals: Continuity and Change in English Political Thought (Oxford: Clarendon Press, 1988). 
principle that only enlightened principles shall be the basis of political order. It supposes, as Edward Caird put it, that 'each thinker must begin the work of speculation de novo. ${ }^{76}$ All authority is rejected as a source of Enlightenment. If 'the Enlightenment' is to be - sancta simplicitas! - a singular phenomenon then it is this: the rejection of the older, religious enlightenment. This is Radical Enlightenment, the Enlightenment of the philosophes.

Perhaps the most complicated form of Enlightenment - the one least understood now - is Sceptical Enlightenment. It may have been too fragile a construction, an interim construction which was blown apart by the events of 1789 . It is for this reason that I think that the 'masterpiece of the century', as Rousseau put it - the belief that the public good is an unintended consequence of separate private actions - is still not fully understood today by more than a few historians of seventeenth and eighteenth-century political thought. ${ }^{77}$ It should be known by others, by historians of political thought from the nineteenth century onwards, perhaps by all historians of political thought, and certainly by all political philosophers: since much of the complexity of modern thought can only be made sense of in terms of its obsolescence.

In comparison to this, Liberal Enlightenment, though it would make little sense to anyone before the nineteenth century, is, in the West at least, the condition we currently enjoy. It is complicated, but not as complicated as Sceptical Enlightenment. It is the Enlightenment of, to use Halifax's great word, a Trimmer.

All three types of Enlightenment seek understanding or awakening. But they seek it in decreasingly coercive ways. The first wants to impose betterment. The second wants to understand the actual laws of history, not to impose betterment, but to understand how betterment emerges out of the actual and concrete practices of humans. The third wants to establish the conditions for humans to seek their own betterment.

All three have a view of history. The first wants to divide it into two, an absolute before and an absolute after. The second wants to leave it as it is, but understand it in terms of its deeper meaning, a meaning to be revealed by study. The third wants also to divide it into two, but not by rejecting older beliefs: only by putting these older beliefs in a new frame.

All three, consequently, have an attitude to religion. The first wants to abandon it completely. The second wants to use it, practically, but see through it,

76 Quoted in James Schmidt, 'Inventing the Enlightenment: Anti-Jacobins, British Hegelians, and the "Oxford English Dictionary", Journal of the History of Ideas 64 (2003), pp. 421-43, at p. 422 .

77 See, for instance, the authors cited in note 44. For a discussion of the 'masterpiece' see Istvan Hont, Politics in Commercial Society: Jean-Jacques Rousseau and Adam Smith (Harvard University Press, 2015), p. 70. 
theoretically. The third wants to retain it, while locating all religions within a secular civil order. In other words, the first is implacably opposed to religious beliefs, the second subverts them, but only for an elite which does not believe in them but is capable of understanding the purpose these beliefs serve even when they are wrong, and the third accepts all religious beliefs but only with the provision that none of them lays down the foundations of civil order: a civil order shall be irreligious so that all religious may exist alongside each other. And just as each may be distinguished in relation to religious beliefs, each may be distinguished in relation to history - because each form of Enlightenment involves a subtler appreciation of the merits of religion - so that the first sees Enlightenment as revolutionary since its beliefs are opposed to the older ones, the second sees Enlightenment as unrevolutionary and even unprogressive as it embodies an elite 'double truth' about religion, and the third sees Enlightenment as the co-ordination of rival truths in a new frame and thus a step forward in progress.

All this repetition of the differences between the three types of Enlightenment should have hammered home the point that Enlightenment cannot refer to anything that happened within a certain historical era, that of the eighteenth century. Something has to change in relation to the old order for Enlightenment to mean something. So the term 'the Enlightenment' should not be used carelessly to denote an era or period or age, though we may want to use it for movements which were first manifested in one particular century. Enlightenment is a general term, meaning a process of awakening or clarifying or illuminating, so that the light comes into the dark. Enlightenment, in the sense we have become accustomed to - Enlightenment in its 'heavily reified' sense - means a secular process of awakening or clarifying or illuminating. Specifically, to speak of 'the Enlightenment' means that we suppose that we are able to identify what such a secular process specifically refers to. What I have claimed in this article is that as soon as we speak of 'the Enlightenment' we are, by necessity, referring to any one of three specific Enlightenments. And my hope is that from now on that if historians and philosophers are to refer to any one of the three, they should feel encouraged, for the sake of completion, to acknowledge the existence of the other two as well.

\section{Conclusion}

So, as a final repetition, I shall offer a definition of Enlightenment in triplicate. Enlightenment is: 
1. the establishment of a rational secular order: that is, a rupture with the older civil order based on tradition, authority and religion so that the newer civil order shall henceforth be based only on rational and secular ideals - for the sake of human betterment;

and:

2. the discovery that human betterment has been the result not of conscious adoption of any particular civil ideals but has been the unintended consequence of many humans seeking to satisfy their own private interests: and also the discovery of the laws by which this betterment has taken place: hence the avoidance of old superstitious civil ideals (which are to be explained but not used in explanation) and instead the pursuit of a science of society - for the sake of human betterment;

and:

3. the realisation that human betterment should not come at the cost of forcing humans to abandon their beliefs or rationalise them away: instead, the realisation that beliefs have meant what they have meant to the believer, and that human betterment will best be served by creating a civil order in which believers in any reasonable belief can co-exist: the necessary condition of this co-existence being that all accept a shared order not itself based on any one set of beliefs: that is to say, a liberal order.

These are not the same. They are contradictory, utterly contradictory: one involves taking one side, the next involves subverting both sides, and the next involves accepting but reframing all sides. Yet they are the elements - the essential elements - of what we have come to call 'Enlightenment', or, historically, 'the Enlightenment'. The contradictory nature of Enlightenment does not mean we should stop talking about it. It just means we always need to specify which Enlightenment we are talking about and also need to admit at every point that, whether named or not, 'the Enlightenment' was and 'Enlightenment' since the eighteenth century has been never anything less than all three of these things at the same time.

\section{Acknowledgements}

This article, originally written in 2018 , is indebted to John Robertson - whom I met by chance at a conference about another subject - for a suggestion about the writings of J.G.A. Pocock which though slight (the suggestion, not the writings) was fundamental and led me to redraft the second half of the article in 2019 and thus to sharpen the eventual argument. 